\title{
On the Possibility of a Synthesis of Secular and Religious Values in the Context of Modern Humanitarian Knowledge*
}

\author{
Olga Chistyakova \\ Department of Social Philosophy \\ Peoples' Friendship University of Russia \\ Moscow, Russia \\ olgachis@yandex.ru
}

\begin{abstract}
In the sphere of Russian humanitarian knowledge, there is a tradition of separating the secular and religious education. The author substantiates that the spiritual and cultural basis of the modern Russian society should be based on universal human values, as well as on centuries-old heritage of the national culture. Orthodox Patristics discourse is derived as a possible model for a kind of Russia's spiritual Renaissance and as the basis of the Russian humanitarian education. The article represents the author's position in consideration of the secular and religious (Christian) norms of morality from the point of view of their unity, significance for both churched and unchurched people. The ideas and concepts of Eastern Patristics are justified by the author as universal spiritual values, ideals, that in the modern world should be the object of not only theological or philosophical reflection, but also be a part of a general humanitarian education.
\end{abstract}

Keywords-Byzantine Greek Patristics; Christian anthropology; secular and religious values; spiritual culture; allhuman values

\section{INTRODUCTION}

There is a strong tradition in the sphere of the Russian philosophical knowledge to separate a priori secular and religious notions, secular and religious (Christian, in particular) humanism. For decades, the existing humanitarian study guides begin with an artificially established contraposition of philosophical and theological Weltanschauung without the search for the possible common ground.

It seems, however, that the reliance only on the scientific knowledge will never make a person more humane as humanity is born from the eternal search for the meaning of life, unfathomable by a purely scientific thinking. Spirituality and the morals do not depend on the degree of mastering the results of scientific research and studies. The longing of an individual for the lofty ideals can never be replenished

*This paper was financially supported by the Ministry of Education and Science of the Russian Federation on the program to improve the competitiveness of Peoples' Friendship University (RUDN University) among the world's leading research and education centers in the 20162020. (The Agreement number 02.A03.21.0008). purely by science. A. Einstein wrote with an inherent wisdom: "Humanity has every reason to put the heralds of moral values higher than the discoverers of scientific truths". The author of the following article suggests concepts and basic ideas, allowing to partially overcome the artificially constructed gap between secular and religious knowledge and, broadly, between secular and religious culture

\section{AXIOLOGICAL GROUNDS OF THE RUSSIAN CULTURE AND EDUCATION}

The occurred tear in the archetypes of culture, the social memory of the generations, associated with the radical social changes in Russia, has led to the ontological condition, which can be described (following L. Feuerbach and $\mathrm{N}$. Berdyaev) as "the godlessness of the world". The tragedy of the current situation is that an individual, that was once considered as the supreme transcendent force, showing truly divine qualities and abilities (cf. The theandric ideas of the Russian religious philosophy), has almost lost the status of the highest value, of the "crown of the Universe" (Gregory of Nyssa). The postmodern philosophy calls this period the post-secular one, for which the rejection of faith and the religious self-identity becomes of the essence [1]. A modernday person is viewed at best as the center of social relations, aimed at the active economic and political reconstruction. Dormant spiritual arsenal of such a "reconstruction" is seen purely in the secular values of culture, and a positive role of religion is not mentioned [2]

However, the Russian theoretical research of the recent years shows a trend toward the restoration of some of the basics of life and consciousness of the Russian people, which has deep historical, ethnic, and religious roots. The restoration of moral principles, spiritual values, religious imperatives, which had functioned previously in the public consciousness, is reviewed as a possible paradigm of the Russian culture development. Yet it is obvious, that it is impossible to reproduce purely, precisely any form of cultural and social life, that had once existed, as the historical-cultural process if irreversible. The need to return to the national origins is seen from the point of view of identifying their significance for the analysis of the processes 
that occur in our society today, as well as for the resumption of the continuity of cultural development [3].

The spiritual and cultural basis of the modern-day society should be based, first, on universal human values, and, secondly, on the archetypal basis of the centuries-old national culture. Therefore, it's absolutely vital today to remember and use the native system of the cultural values [4]. It seems that the inclusion of the said system the moral ideals begin to run, turning into the effective factors of selfactualization and self-identification. At the same time, some cultural traditions, subjected to philosophical reflection, could serve as moral principles of modern culture, filling the spiritual vacuum, and could be presented as a certain cultureforming principle of the spiritual life of the Russian state.

We are talking about the Patristics legacy and cultural heritage of Christianity. Created in the 4th-7th centuries by the Holy Fathers of the Church, the Orthodox anthropology teaches an individual to comprehend own spiritual essence, to realize own creative potential and to search for oneself in a complicated contradictory world. Isn't that because of the anthropological ideas of Orthodoxy, expressed once by the Slavophiles, have always been an immanent component of spirituality in Russia? The legacy of the Eastern Christian Patristics is a special model of high culture, in which philosophical ideas are being begotten, allowing to some degree to comprehend the contemporary era with all its complexity and intricacy. The correlation to the Patristics' ideals does not mean blind copying or imitation. The Holy Fathers tradition provides if with an opportunity to realize, just how applicable this kind of culture is for the education of a modern man, for the approval of his creative powers, for self-realization.

The Orthodox Patristics discourse as possible but the not absolute model of a kind of spiritual Renaissance of Russia has the positive feature of independence from the official state, political, social, and economic settings and conditions. The main ideas of the Eastern Patristics, despite the distance in centuries, justify the progressive development of spiritual culture and mentality, outline a way to overcome the cultural crisis, which is seen as the lifting of the people's spiritual creativity, the rejection of irresponsibility, the priority of rationality, not excluding, however, the value of a human personality.

The author of the article doesn't advocate a sharp contrast of secular and religious humanism, i.e. secular moral norms, ethics, rules of human behavior with the religious (Christian) ones. The basis for this statement is formed by the ideas and concepts of the Orthodox Patristics, that, in our view, may claim the level of philosophical reflection, since they bring to the discussion universal human spiritual and ideological concepts, cultural values and imperatives of human behavior, becoming a subject of not only theological but also, philosophical consideration. These Orthodox standings may quite naturally enter the national system of spiritual values since they correspond to the historical-cultural archetype of the Russian mentality.

The idea of reflection and restoration of the best Orthodox values can be accused of utopianism, absolutism, or, vice versa, of limitations (after all, Georges Florovsky said that "by no means everything ... is Orthodox in the Russian soul"), but in the essence the idea is not refuted by criticism, nor history. We would like to outline some ideas of Patristics that we deem relevant and not so far from secular values, as it is traditionally assumed.

\section{CUltural Heritage OF EASTEN PATRIstics}

If we rewind to the era of the formation of the Christian dogma (4th - 7th centuries AD), when the Holy Fathers worked, we'll see that then a new style of "cultural behavior" was evolving gradually, distinguished by the predominance of the universal human values over the national or class ones, and humanistic orientation, refocusing ethical concepts in the direction of spirituality, was steadily entering the general development of culture, alongside "canonization" and "authoritarianism". Concurrently Christianity didn't prevent the various ethnic groups from preserving their own peculiarities or "cultural style". A distinctive feature of Orthodoxy was the cultivation of the value of personal existence, moreover, the affirmation of human life in the name of eschatological salvation became a kind of end goal of that cultural paradigm.

The center of the Byzantine Orthodox culture was the understanding of an individual, his essence, the expediency of existence. An individual in the works of the Holy Fathers is found between society and God, therefore the relationship between them is a personal and living communion in the spirit. The philosophical setting of the Orthodox anthropology is that an integral individual, anchored in the depth of earthly existence by the right of possession of the image of God and inspired by the Holy Spirit, may serve as the basis and purpose of things in the objective world.

Spiritual components of a human represent partially unexplainable phenomena, so they belong to the sphere of transcendental, i.e. beyond nature. The expression of the transcendence, the spiritual beginning of an individual, according to Patristics, is the possibility of achieving a "likeness" to God. The ground for this the Orthodox thinkers saw in the following "deified" human traits: freedom of will, reason, love, wisdom, virtue, etc. The gradual acquisition of these qualities is a dynamic process of continuous spiritual perfection (theologists call it "deification"). The Holy Fathers were trying to solve a problem, how an individual, a priori having the perfect spiritual powers, enters the phenomenal world, and how can he make a breakthrough in the "noumenal", i.e. the divine, world. The consciousness, reason, soul are not only psychological phenomena but are connected, from the Patristics' point of view, with the Holy Spirit. A human remains imperfect until being encouraged by God. Saint Irenaeus wrote in the 2nd century: "When the spirit, allied to the soul, links with creation, then a human becomes, by the reason of the outpouring of the spirit, spiritual and perfect" [5].

Exactly the spirit in the Orthodox cultural tradition, appearing capable of leading the people beyond the objective world, is the condition of possible transcendence of a human, which is achievable only in the perfection of nature, common 
to everyone, universal, general, that Gregory of Nyssa called the "unitotality" of human race. By approaching the absolution through "spirit" and "reason", a person becomes overt to the Divine.

The Patristics tradition shaped a contradictory image of a human, able to rise to the Absolution, perfect, but also unaware of the own high purpose and thus tending to the subjects of vile, infamous. These ideas were immanent to the first Christian thinkers - Lactantius, Saint Irenaeus, Athanasius of Alexandria, Gregory of Nyssa, Basil of Caesarea and others. Religious sages derived the image on the only creature in the world, able to eliminate the dualism of the divine and earthly worlds and to reconcile the spiritual and the material existence. From this challenge grew the "cosmic" goal of the universal personality: to lead the earthly imperfect world to harmony and absolute agreement. Gregory of Nazianzus (4th century AD) defined remarkably a human as a being, "settling a feud" of spiritual and material. He wrote: "I consist of body and soul. And the soul is the infinite jet of endless light - Deity; and the body is made from the dusk beginning. If I constitute one common nature: this feud is settled... For not the hostile but friendly beginnings provide common product" [6]. Human nature is directed at spiritual equality with God and, therefore, at the establishment of absolute harmony in the world of "created" things.

Maximus the Confessor argued that the main purpose of a human is the unification of the earthly world with the Logos, but to achieve that an individual should undergo internal deification first, as he is the microcosm, integrating all the elements of macrocosm and the Universe. These ideas show the greatness of the human destiny, as well as the tragedy of existence because of the unfeasibility of the aforementioned purpose because of a misunderstanding and abuse of freedom.

The issues, raised by the Holy Fathers at the dawn of Christianity, force modern people to ponder the meaningful questions of a modern individual. What is the greatness of a living person? How should it be implemented? How may our fellow man draw strength to maintain the high purpose and implement the moral mission?

\section{THE SUCCESSION OF THE PATRISTICS' IDEAS IN THE RUSSIAN RELIGIOUS PHILOSOPHY AND THE HUMANITARIAN EDUCATION IN MODERN RUSSIA}

An interesting continuation of the Patristics' ideas will find its expression in Russian religious philosophy, which, assuming the theological method of the Holy Fathers, was aimed at justification of the idea of deification and provision for an integrity of an individual. The representatives of the Russian spiritual Renaissance emphasized strongly the succession of their creative aura to the Patristics' tradition. The founding father of the Slavophile movement Aleksey Khomyakov argued that Orthodoxy is rooted in the moral and psychological life of the Russian people. He believed, the neglect of the own roots can lead to grave consequences.
Anthropology of Russian existentialism is the best confirmation of the perception and development of Patristics' ideas. N. Berdyaev asserted, that personality is not a particle of the universe or family but rather otherwise, society is a part of an integral person, as the basis of personality is the spirit, which brings an individual from the world of objectification into the trans-subjective world to meet with God. Berdyaev noted: "The triumph of the spiritual beginning doesn't mean subordination of an individual to the universe, but the revelation of the universe in an individual" [7]. Society and state are the limits to human freedom. So, the antimonies of an individual and the society can never be completely overcome within the natural historical and social world. Therefore, the problem of an individuality and society could be solved from two standpoints - the philosophy of society and the philosophy of spirit. Any form of society is, in fact, tyrannical in respect to the identity, human spirit ("the slavery of being"). Therefore, the solution of the said problem is possible, according to Berdyaev, in the framework of the philosophy of spirit from the perspective of Christian personalism.

The ground stone of Berdyaev's teaching is the recognition of an individual as a spiritual being and spiritual unity of people based on love and service to God. For this union to be implemented, there should occur a transformation of a person through the world of culture, values, creativity. Spiritual community only frees a man. "Spirit is freedom, and freedom is the victory of spirit" claimed N. Berdyaev [7]. The history of the society, from his point of view, is a theandric process, having an eschatological meaning. Yet, hope for the future relates to the appeal to the objectified world and an enlightenment through the intelligent creativity of a person. There should be an effort of the spirit to prevent the decomposition, split and disintegration of the self. People without creative impact on the world and self "have no face".

The situation of Berdyaev's religious personalism, in our opinion, are relevant nowadays. The world of "objectification" has so captured a modern human that profound ancestral spiritual foundations of a human personality are now forgotten. The concepts of unitotality, collegiality, freedom of will, the belief in the absolute spiritual potential, mercy, and compassion as the foundations of the soul, once elaborated at the dawn of Christianity and Orthodoxy, have become distant and unpopular. Lost is the inner spiritual center of command of the soul. And the view of the spiritual beginning of a human as his supreme element was inherent to the Russian religious philosophers. A human was seen as a brilliant idea of God (N. Berdyaev).

In this perspective, it is very topical and important is the idea of Greek Byzantine Patristics, "highlighting" the meaning of human life: an individual is obliged to elevate the mind above normal, natural level and to hunt down the roots, that associate an individual with the entire human race. However, these ideas should be used with extreme care. The call for the restoration of the human race should not grow into the idea of total subordination of an individual to society and state. Therefore, the problem of the relation of a man's spiritual freedom and his limitations by the various social 
and economic forms of dependence remains a thin line where a bias is fraught with dangerous social and psychological consequences. We should remember that collegiality, upon which called the Slavophiles and the Russian religious philosophers, is a reconciliation of each and everyone's freedom with the unity of all on the basis of spirituality and Christian love. As for the Byzantine thinkers, the individual spirit is the fundamental level of human reality, then the idea of inner spiritual rebirth, performed in a free (not forced) way, has always been meaningful and relevant. Gregory of Nyssa noted in his remarkable work "The Making of Man", that the personality is deliverance from natural necessity, the ability to free self-determination, the ability to transcend the individuality in order to reform it in accordance with absolute regulations and values. Let us now consider, is an everyday person able to mentally and practically identify himself with the cultural values of his own people (not to mention the world's cultural and civilizational achievements). Enslaving impact of economic and social decline set in a contradiction between a man and culture, a man and the Absolution, that a believer may call God, and an unbeliever may call the Good, Virtue, Reason, Spirit, Beauty, Truth.

Human freedom in the works of the early Orthodox thinkers was directly set in accordance with reason, rationality, and human activities. A person knowingly "leads his nature", executing power over his actions and desires argued John of Damascus. The process of personal selfidentification was seen by the religious thinkers as coinciding with the process of knowledge of God and selfknowledge. At the same time, the reveal of the selfknowledge possibilities in theology had a secular value, as it put the emphasis on the cultivation of internal qualities and properties of a human, developed the one's psychological characteristics, "taught" the art of control of the entire multiplicity of the energies, thoughts, and aspirations.

In the Orthodox anthropology, the human self-knowledge is a feeling of self and a "way to oneself", i.e. the process of self-identification and self-awareness through the search of moral ideals through the juxtaposition of own deeds with the Absolute morality of God. Personal consciousness and knowledge of the Divine grow, as a man becomes more and more perfect, free. But in Orthodoxy, this is "freedom from": from sin, the world, feelings, and hardships of flesh. So, it turns out that the focus on spiritual values has contributed to the affirmation of an individual, but, at the same time, in the implementation of this idea of asceticism, the aforementioned orientation has narrowed the field of freedom [8].

Sure, the knowledge of the Divine truths in Patristics and the philosophical cognition are two different things. It's impossible to comprehend the depth of God with the help of philosophical concepts (as tried Hegel), and the Patristics thought was quite far from that, so the only way to the knowledge of God, suitable for the Holy Fathers, was the apophatic one, negating what couldn't be God. The Greek Fathers of Church, having wonderful classical education, resorting to the categories of Greek philosophy to explain the truths of Revelation, had never substituted a living, personal communion with God by thinking about Him in logical constructions and dialectical concepts, didn't substitute personal God with the impersonal Absolution ("God of philosophers"). The Holy Fathers took an Individual to the foreground of God, showing in the Trinity the golden standard of interpersonal relations, based on equality, involvement, spiritual unity. Without denying, as we have mentioned, the value of reason in theology, they believed, that the vision and contemplation of God (and, hence, selfknowledge) is only possible through personal cleansing, moral perfection, paired with ascetic "smart doing".

Individual experience in the knowledge of God ad selfknowledge in the works of the Holy Fathers, and then in the Hesychast tradition, involves the transformation of human nature under the influence of the supreme Divine power, as well as under the active position of the person himself. A person shall mold his inner world to perceive the higher ideals and ideas. Of course, in the interpretation of the religious thinkers, the ultimate purpose of man is to achieve the unity with the Deity. Gregory Palamas wrote: "It is impossible to truly become close to God unless in the process of cleansing ourselves we will not go beyond, or, better to say, above ourselves" [9].

\section{CONCLUSION}

It is significant for a secular person that the Patristics idea outlines one of the mechanisms of an individual's selfidentification, defines the human purpose as a creative pursuit for the acquisition of the existential values. The most important religious-philosophical statement, still maintaining its rationality, stemmed from the setting of a human being at activity and faith: the perfect life - both personal and public - is being created naturally and really by an individual himself. An individual should be freed from the "bondage of society, state, nature, civilization", so Berdyaev, however, the line between freedom and anarchy should not be crossed, or else the beautiful Christian postulate of the freedom of human self-determination becomes a mean of justification of violence, permissiveness, and chaos.

There are many ideas, claiming to be "eternal" truths in the Orthodox Patristics heritage. The time has come to carry out the synthesis of humanitarian knowledge and the selected religious ideas and values (and not only Christian), it is time to overcome finally the barrier of the fear of religion. Yet, the synthesis must be done not eclectically and superficially, but in historical-philosophical perspective, deeply comprehending and raising for discussion the layers of religious culture, that are now forgotten.

\section{REFERENCES}

[1] O. Chistyakova, A View on Contemporaneity through the Discourse of Postmodernism // Proceedings of the 2017 2rd International Conference on Contemporary Education, Social Sciences and Humanities. (ICCESSH 2017). Advances in Social Science, Education and Humanities Research. - Moscow, Russia. 14-15, June 2017. - Paris: Atlantis Press, 2017, pp. 96-100.

[2] M. Matyushova, Art in the Era of Postmodernism // Proceedings of the 3rd International Conference on Arts, Design and Contemporary Education (ICADCE 2017). Advances in Social Science, Education 
and Humanities Research, volume 144. - Paris: Atlantis Press, 2017, pp. 68-70.

[3] T. Leshkevich, Philosophical Meaning of Modern Transformations of Education // Proceedings of the 2017 3rd International Conference on Arts, Design and Contemporary Education (ICADCE 2017). Advances in Social Science, Education and Humanities Research, volume 144. - Paris: Atlantis Press, 2017, pp. 651- 653.

[4] O. Chistyakova, Russian Religious Philosophy as the Basis for State Identity // Journal of Eurasian Research). - 2003. - Vol. 2. Ed. 1. Washington, DC, pp. 13-17.

[5] Saint Irenaeus. Works. - M., 1996, p. 456

[6] Gregory of Nazianzus, The Word on Peace // Works. In 2 Vols. Vol. 2. $\mathrm{SPb}$, without year, p. 25.

[7] N. Berdyaev, Slavery and Freedom // Berdyaev N.A. The Realm of Spirit and the Realm of Caesar, M., 1995, p. 17.

[8] O. Chistyakova, Postmodernism, Christian Patristics, and Values of Peace in the Modern Cultures. In the Context of Educational Process // Proceedings of the 2016 International Conference on Arts, Design, and Contemporary Education. Volume 64 (ICADCE 2016) Advances in Social Science, Education and Humanities Research». Advances in Social Science, Education and Humanities Research». - Paris: Atlantis Press, 2016, vol. 64, pp. 996-1000.

[9] Gregory Palamas, The Conversations. In three vols, vol. 3, M., 1994, p. 116. 